\title{
Effective Networking Model for Efficient Implementation of E-Governance: A Case Study of Nigeria
}

\author{
Lauretta O. Osho \\ Federal University of Technology, Minna, 920001, Nigeria \\ Email: laurettachristi@gmail.com \\ Muhammad B. Abdullahi, Oluwafemi Osho and John K. Alhassan \\ Federal University of Technology, Minna, 920001, Nigeria \\ Email: \{el.bashir02, femi.osho,jkalhassan\}@ futminna.edu.ng
}

\begin{abstract}
Nigeria is a nation full of potentials ranging from its human resources advantage to its mineral resources - the list is endless. Ambitious too, it has come to terms with the fact that ICT must be utilized even for the delivery of democracy dividends to actualize its vision of being among the top 20 economies by year 2020 . In this paper, we explore the nation's drive towards adopting e-governance by generally itemizing the requirements for e-governance, appraising how far Nigeria has gone in implementing it and then proposing a workable way to achieve it. Our study reveals that while the visions for e-government implementation are well articulated in terms of required components and intended deliverables, there are no clear statements on the processes of implementation. To this end, we propose some networking models adoptable towards realizing the different dimensions of e-government.
\end{abstract}

Index Terms-Democracy, e-governance, e-government, government, ICT, implementation, networking model, Nigeria, vision 202020.

\section{INTRODUCTION}

Every nation is as strong as its governing system. The government and people of a country are the two important elements that make up a workable, effective and growing nation, as far as both parties play their role efficiently. A government is a group of people that have the legal right to govern a nation. Any type of Government should have a way of affecting the activities of the people in several useful ways [1].

Communication and implementation of what has been communicated is a vital ingredient in the governance of a successfully growing economy. However, both are more appreciated when they are seamlessly conveyed, timely, and in the most cost-efficient way. It benefits both the government and the governed. The need, therefore, to make the relationship between the government and the governed easier and more flexible cannot be overemphasized.
The level of advancement in information and communication technology (ICT), in recent time, has clocked an alarming rate. Its use has permeated virtually every facet of human endeavors, providing the means to ensure ease and efficient processing and delivery. Today, words like E-government and E-governance have come into prominence. E-Government refers to the use of information technology by the government for the exchange of information and services, while e-governance refers to the process of using technology to share information, provide services, and transact businesses between the government, other arms of government, government agencies, businesses and the citizens. E-Governance covers the whole range of inter-connections within government in respect of the application of ICTs to serve the citizens. The adoption of e-governance has attained a world-wide dimension. Today, most advanced countries of the world have advanced in the implementation of e-governance. The benefits are immense. The developing countries, African countries inclusive, are now beginning to embrace this method of governance to deliver more citizen-focused, cost-effective and efficient services to citizens and businesses, whilst improving internal processes of government [2].

Nigeria as a nation runs a democratic system of government (Government of the people, for the people, and by the people). As a developing country, it is striving in order to attain the world's standard in terms of economic, educational, infrastructural, communication and commercial growth, and development. Several developed countries like the United States of America and China have not only successfully implemented an e-government system but also have been able to transform its activities to a working e-governance system.

Although, Nigerian government has made attempts to build a model that was presented and the endorsement was given at one of the United Nations organized International Conferences for Electronic Governance (ICEGOV2007), a total implementation of e-Government in Nigeria would avail it the opportunity to be on equal level with developed countries globally. 
As Nigeria grows democratically, the need to develop her capacity to meet the growing challenge of meeting the needs and demands of the citizens equally grows. A sizeable number of the population is found in rural areas. These also deserve to enjoy the benefits that democracy affords. Therefore, the need for government to diversify its means of service delivery, through the adoption of e-governance, cannot be over-emphasized. In other words, considering the benefits enjoyed by countries which have adopted e-governance, there is no better time than now for Nigeria to embrace technological means in disseminating information to the people, sharing ideas between different sectors, listening and responding to the views and complaints of the citizens. Currently, there is a big communication vacuum between the government and the citizens which, if not addressed, would only lead to gradual degeneration in governance in Nigeria.

Considering the level of ICT acquisition and knowledge in the country, care must be taken to determine the most efficient networking model to support a pragmatic implementation of e-governance in Nigeria.

This study is aimed at proposing a networking model that will most effectively support the efficient implementation of e-governance in Nigeria. To achieve the above aim, we would seek to achieve the following objectives: survey e-governance and the requirements for its effective implementation, appraise level of ICT utilization for the implementation of e-governance in Nigeria, and propose a networking model that would best suit e-governance implementation in Nigeria.

In this study, the focus is on the propositioning of a suitable networking model that would best support the implementation of e-governance in Nigeria, based on the present realities. This study takes cognizance of the scope of government's aspirations to actualize the delivery of governance electronically. Thus, the networking model should be able to support the goals and visions of government relating to e-governance implementation. This study does not go beyond trying to achieve Nigeria's vision 202020 electronically.

This study is meant to promote the adoption of e-governance as a better form of governance for both the government and the governed. It will also help the Nigerian government to select the best mix of ICTs to use so as to effectively support an efficient implementation of e-governance. In essence, the proposed networking models could go a long way to help Nigerian government in selecting a pattern to follow when trying to achieve an effective model for e-governance.

\section{LITERATURE REVIEW}

\section{A. The Essence of e-Governance}

The term e-Government (or electronic government) is only a recent thing and there is no standard definition for it as a full understanding of the concept is still evolving. Basically, e-Government implies using information and communication technology (ICT) by government agencies for information exchange, promoting a faster service and ensuring more efficiency in the delivery of public services. Its advantages are numerous. They include improved general efficiency, costs reduction, increase in revenue, and effective administrative processes. The essence of e-Government can be said to be for enhanced value for stakeholders through transformation. However, conventional delivery systems will continue to be important since the internet coverage area is limited, spread of education is restricted, and there is gross inadequacy in infrastructure like power, good roads, hospitals, schools, to mention but few. [3].

Fig. 1 [4] depicts the goals and soft goals (objectives), described by the EU Ministerial Declaration on e-Government (2009), which could serve as a model for any country that aims to reap the full benefits of e-government.

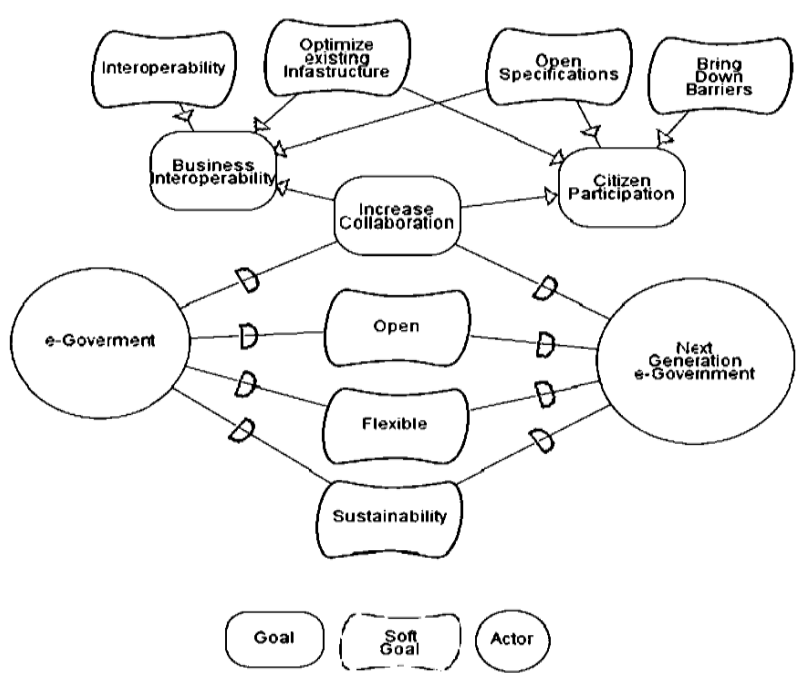

Fig 1. An e-government framework

\section{B. Categories of e-Governance}

Some main categories of communication in e-governance delivery or developmental models have been highlighted as follows [5]:

- Government-to-Citizen or Government-to-Customer (G2C) - this involves interactions between the government and the people either directly or indirectly.

- Government-to-Business (G2B) - this involves interaction between government and the business enterprises that affect governing and the government.

- Government-to-Government (G2G) - this involves interactions between one government agency and the other or between one arm of government and the other to share ideas and avoid conflicting roles and opinion.

- Government-to-Employees (G2E) - this involves the interactions between government and all the staff or people involved directly or indirectly working in government establishments.

C. Dimensions of e-Governance 
Sakowicz [6] and [2] highlighted some dimensions of e-governance that explains some activities that e-government is involved in, thus:

- E-services -This is the use of electronic delivery for government information, programs, strategies and Electronic Service Delivery (ESD).

- E-management - this refers to the background system that supports the overseeing of public infrastructure in addition to data information management, electronic records maintenance and inter-departmental flow of information.

- E-democracy - This is the feature of e-Governance which is used as an instrument for setting agendas, establishing priorities, making important policies and participating in their implementation in a deliberative way. It includes virtual town meetings, open meetings, cyber campaigns, feedback polls, public surveys and community forums. It is quite difficult to generate and sustain e-democracy.

- E-commerce - this relates to the business part of government interaction. Here the exchange of goods and services with money is done over the Internet. For example, payment of tax and utility bills, government buying office supplies, renewing the registration of your vehicle, and paying for recreation programs, and auction sales through the internet.

\section{Models of e-Governance}

Adejuwon [2] also highlighted some important e-governance models:

- Wider Dissemination Model - This model is based on what the government is willing to make available to the general public. These are information such as government plans, expenses, budgets, decisions on citizens' rights, government performances and any other information that is useful for present and future decisions as well as useful contact addresses.

- The Critical Value Information Flow Model - This information is based on the dissemination of information just to a specific set of audience electronically. Information that are sensitive can be given out such as corruption data, reports of enquiries that are useful to certain organizations or agencies, very confidential information etc. to concerned citizens and NGOs and giving information like radioactive spills, effluent discharge, etc. online to local inhabitants.

- Comparative Analysis Model - This is a model based on the fact that information about the services or products that the government gives could be compared. This information could be past information useful for future decisions, evaluating the strengths and weaknesses of policies, ensuring quality decision making and getting quality information.
- Interactive Service Model- This model is also based on the fact that citizens should also be given the opportunity to actively participate in policy and decision making. This could be achieved by establishing interactive communication channel, conducting electronic ballots, conducting public debates/opinion polls, Establishing decentralized forms of governance etc.

It is important to note that for us to have and operate an e-governance system that will bring the desired results, one single model may not be enough as it is not all-encompassing, one may need to merge two or more models to get a most appropriate model which will address the objectives of e-Governance as we have outlined them. This will lead to the achievement of a better e-Governance system for the country.

\section{E. Requirements for e-Governance Implementation}

Efficient implementation of e-governance needs some requirements. Each of the following requirements is needed at either the pre-implementation stage or to support its continuous implementation. Gichoya [7] listed some basic requirements for a successful implementation of E-governance:

- Vision and strategy

- Government support

- External pressure and donor support

- Rising consumer expectations

- Technological change, modernization, and globalization

- Effective project, coordination and change management

- Good practice

\section{F. Challenges in the Implementation of e-Governance}

Adeyemo [8] identified some factors which can act as hindrances to effective e-governance implementation in developing countries like Nigeria. They include:

- An outright refusal or hesitation in information disbursement.

- Management challenges, bringing about insufficient e-Content information from lower levels.

- Total illiteracy or low ICT literacy.

- Insufficient Internet facilities, high cost of internet connection and/or low internet.

- The obvious gap between the rich and poor, rural and urban citizens and IT literate and illiterate.

- Inadequate distribution of financial resources.

- Clear differences and gap between the present and future systems.

\section{G. Related Works}

Guanghua [9], in the paper titled, "E-Government, People and Social Change: A Case Study in China," presented the state of e-governance in one of the 
provinces in China. The author pointed out the fact that China, like many other developing countries, had to grasp with the challenges associated with implementation of e-government. He criticized the focus of the government on the technical aspects of e-government while the political, social, economic, organizational and people roles were not given due attention. Although he faced the challenges of having to listen to the views of many who were against the concept of e-governance, he was able to highlight the crucial roles of middle-level officials and senior management in the e-government implementation process. His research was largely constrained by the fact that it focused on a particular geographical and social area and not generalized such that it could be applied in other locations.

On his own part, [2] examined the transformation from e-government to e-governance and its effects on African public administration. He gave a brief assessment of e-governance in selected countries in Africa and West Africa in particular and its implications on public administration. He suggested that the best contribution of e-governance is improving general relationships between government and citizens. This is in addition to enhancing public services. He advised that Africa should speed up implementation of e-governance so as not to be left behind among other regions in the world; indicating that Africa would not move ahead unless e-Governance was rigorously implemented. He suggested that African government need to develop citizen-centric models that would involve increased participation of key stakeholders outside government, take cautious steps to ensure better reach and access so as to help minimize the increasing problems of corruption and social and economic injustice. He concluded by suggesting that investments in ICT should be integrated into broader developmental agendas in Africa. He however did not expansiate how these solutions could be implemented.

Adeyemo [8] basically reviewed and presented an assessment of Nigeria's global e-governance ranking. Adopting the standards and methodology used by the ranking agencies, he analyzed the nation's performance in the surveys. He was able to identify some of the areas of deficiencies which have affected negatively the delivery of e-governance in the country. This was against the backdrop of the country's giant strides in the development of its ICT and telecommunications sector. He suggested ways in which this situation may be improved, citing improvement of mobile telephone systems, updating of the ICT infrastructures, development of human capital, and review of websites inculcated in a Nation's portal.

Prasannakumar [10] concluded in his paper that e-governance becomes inadequate as a tool for enhanced service delivery once it is not all encompassing in its implementation. He had taken the revenue department in one of the states in South India as a case study. He studied selected service delivery areas including welfare schemes implementation, issuance of certificates, to mention but two. The aim was to determine how far the tools applied in these areas satisfied the people for which the e-governance project was meant for. Although the results of his findings were limited in scope and applicability, he was able to add the collection of taxes using e-mode to his study. He however expressed the challenge of officials being reluctant to accept the solutions and comfort that e-governance proffer majorly for fear of transparency, leading to a drag in the speed at which these solutions can be implemented. He concluded by saying that the service providers as well as those for which the service was provided should be willing to apply new ICT techniques to be able to move forward.

Vijaykumar [11] did a research on impact of cloud computing on e-governance implementation and came to the conclusion that application of cloud computing to e-governance would transform a nation into an information society. He discovered that e-governance brings about change and progress in the economy by providing uniform set of services, changing the people's mindset and simplifying the process. He also noted that cloud computing is a suitable vehicle that will take e-governance to that level of success, providing a solid base to all stakeholders and ensuring that there is a benefit from economies of scale, bearing of social impact and enabling IT advancement.

\section{CONCEPTUAL FRAMEWORK}

Establishing an effective networking model can best be achieved using the concept of process modeling. A Process model represents a networked group of related processes, representing a scheme for accomplishing an objective [12]. While it is used for descriptive and explanatory purposes, process models could also serve to prescribe the flow of execution of processes [13].

Networking, as one of the available ICTs, is an important component of e-government [4]. It deals with the interconnections and communication process among other components that support e-government. Effective implementation of e-governance depends, to a large extent, on the right selection of technology, collaborations, and stakeholders to effectively manage the chosen technology. Another determinant is the topology that stipulates how each component relates with the rest. Poor networking of all required components would no doubt result in poor implementation of e-governance.

\section{RESEARCH METHODOLOGY}

In this paper, we adopt a qualitative research method. Data collection techniques include government websites, materials from forum, workshops on e-government; government policy statements and other official resources; and non-participant observations. Analysis of data is made under the context of the nation's vision towards actualizing e-governance vis-à-vis the nation's e-government e-readiness index. This strategy will determine if there is need for the review of frameworks, or the establishments of new ones. However, we focus on the networking framework. 


\section{A. Nigeria's Path to e-Governance}

Nigeria as a country is presently pursuing a project popularly known as Vision 202020 , which is aimed at becoming one of the 20 biggest economies in the world. By implication it has the vision of being one of the 20 most dynamic and competitive knowledge-based economies in the world by the year 2020. A knowledge-based economy (KBE) is an economy driven by generation, processing and utilization of knowledge using both the human resources and the necessary technology. It is the major input for higher productivity and wealth creation [14].

Achieving this goal of Vision 202020 requires a great deal of national competitiveness, and this is stimulated by a steady national economic growth [14]. Although Nigeria is endowed with a rich and enviable wealth of natural resources that can compete with what is obtainable in other nations of the world, to be able to achieve this goal, it is important to take note that, while it is necessary, possessing natural resources alone is not sufficient. There is a need for adequate human resources to handle and match the bulk of available natural resources.

Human resources, in the public sector, are essential for productivity growth, which is the primary determinant of economic growth. However, achieving this growth calls for harnessing both the human resources and necessary technologies to achieve efficiency in the public sector.

From the foregoing, it is evident that the infusion of information and communication technology (ICT) has become indispensible for any nation to attain, Nigeria inclusive, to attain national competitiveness.

Fig. 2 [14] below summarizes the path from e-government to Vision 202020.

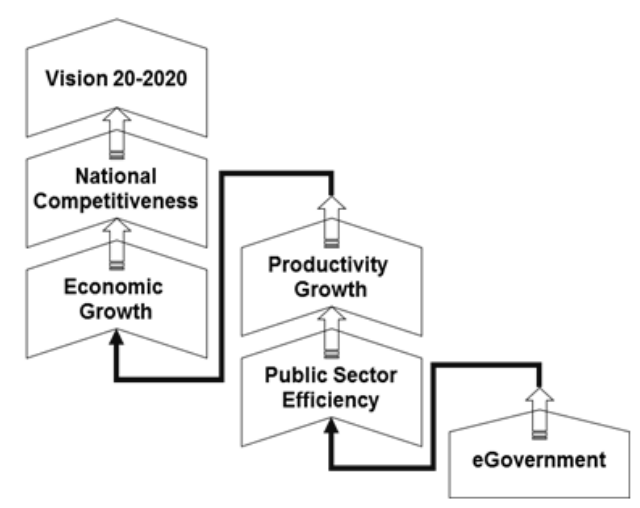

Fig. 2. e-Government as driver for Nigeria's vision

\section{B. Implementing e-Governance}

Over the years, the Nigerian government has invested much effort to put in place certain initiatives towards building an e-nation. Some of these, as outlined by [14] include:

- The introduction of Nigerian Information Technology (IT) policy in March, 2001.

- By April, 2001, the National Information Technology Development Agency (NITDA) was established, with the primary mandate of implementing the national IT policy.

- In March 2004, government created the National e-government Strategies (NeGSt), under a Public Private Partnership (PPP), with NITDA as the representative of the government. This was created as a Special Purpose Vehicle for the implementation of the national e-government programme.

The PPP model for e-government implementation, as represented by Fig. 3 [14], provides for active collaboration between the public and private sectors. While government takes care of establishing enabling laws, policies, and reforms, part funding, and public sector data. On the other hand, the private sector provides technical solutions, infrastructure, and also funding. All these are expected to culminate in improved services to citizens, as depicted by Fig. 4 [14]. The projected e-government platform is represented by Fig. 5 [14].

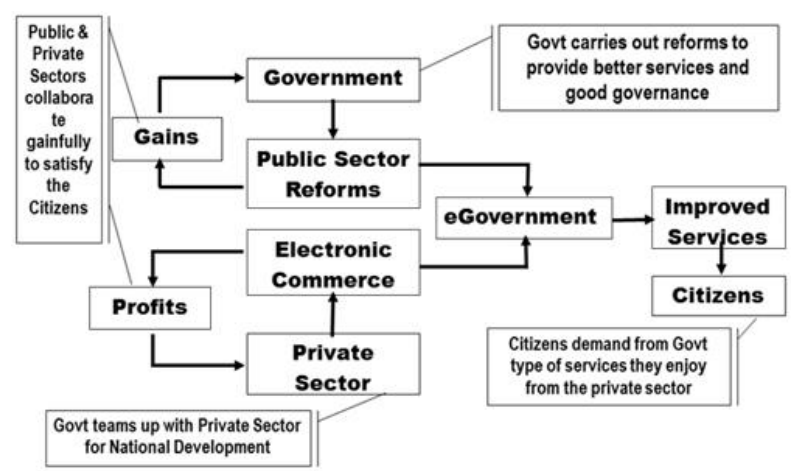

Fig. 3. The Public Private Partnership Model for e-Government

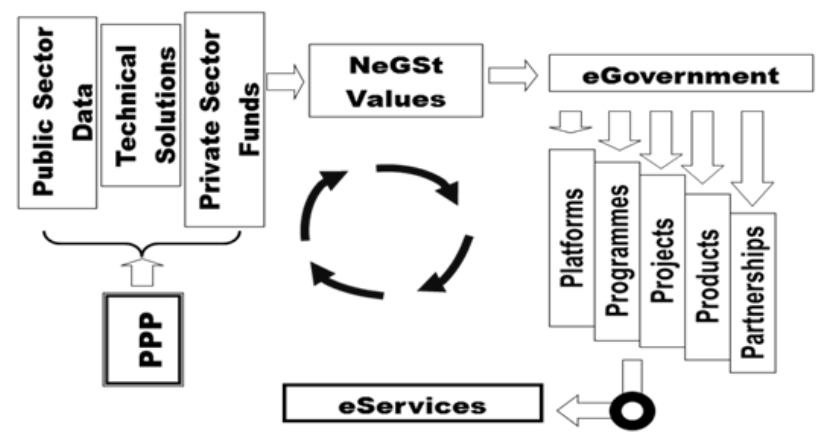

Fig. 4. Mechanism of partnership operations 


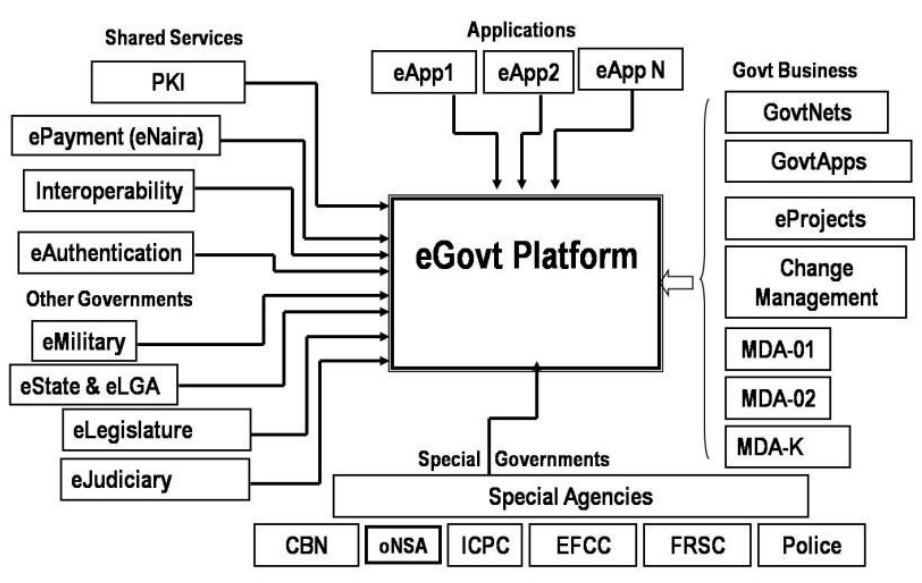

Fig. 5. Projected e-government platform

The stakeholders for the implementation of e-governance are highlighted in Fig. 6 [14]. The actualization of the implementation of e-governance is geared towards achieving a fully networked system.

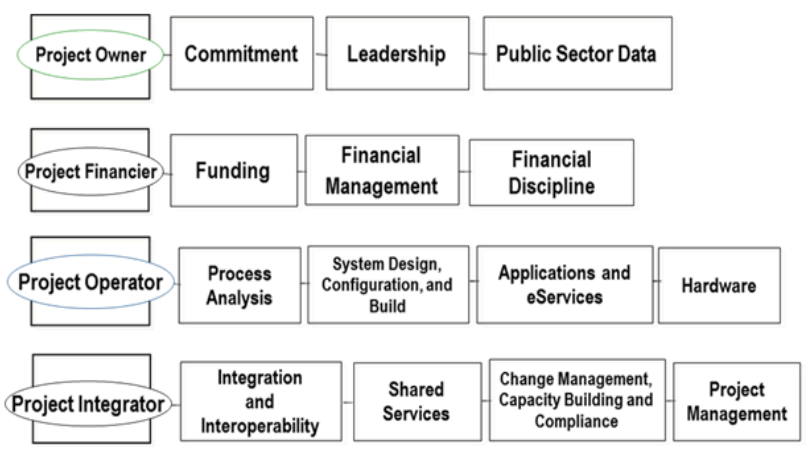

Fig. 6. Key Partners for e-Government implementation

\section{Appraisal of ICT Infrastructures}

Nigeria has undergone a lot of transformations due to IT reforms that have been tending towards the achievement of a workable e-governance implementation. According to [8] and [15], the country has improved greatly in ICT and telecommunications infrastructure over the past couple of years majorly due to the remarkable success in the telecommunications sector. This sector has become one of the fastest growing and most lucrative in Africa. Some of the giant strides in the telecommunications sector include the licensing of mobile operators and internet service providers (ISPs) by the Nigerian Communication Commissions (NCC), submarine fiber optic cable funded by the African Development bank (ADB), launch of the first communication satellite in 2007 by the National Space Research and Development Agency (NASRDA), increased growth in mobile subscriber base and internet services, and increased access to computer hardware and building, and equipping more computer centers in schools by Education Trust Fund (ETF) and Petroleum Trust Development Fund (PTDF). All these have helped in improving the infrastructural index from 0.0013 in 2004 to 0.0492 in 2008 .
Specifically, Nigeria has experienced a great deal of transformations in internet penetration. By the end of 2011, Nigeria ranked $1^{\text {st }}$ in Africa [16], and $10^{\text {th }}$ in the world in respect of the number of internet users. Having grown from a humble 2,418,679 users in 2005 to an estimated 10 million users by 2008 [17], the 2011 estimate stood at $47,143,356$ [18]. Below is the percentage from years $2000-2012$ [19].

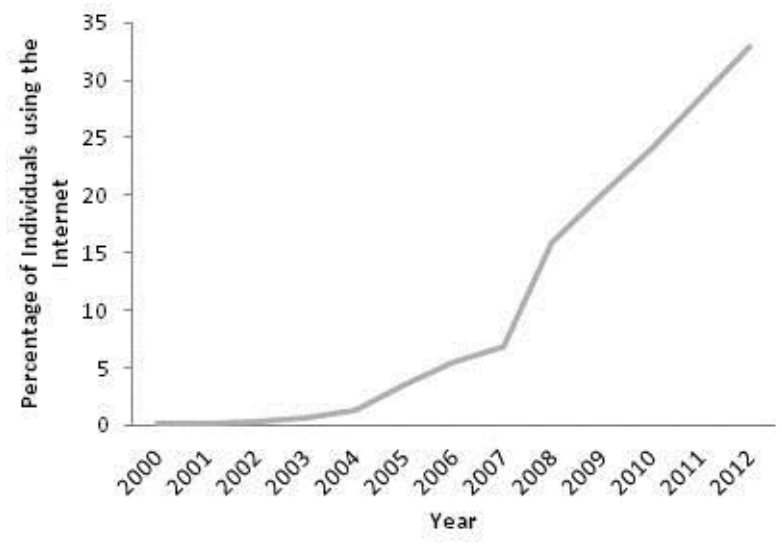

Fig. 7. Line graph of percentage of internet users

In 2006, the Galaxy backbone, a public corporation providing broadband, was established to help provide the technological platform for e-governance which primarily gave rise to the mobile telephone access. Between 2000 and 2008, Nigeria gradually rose to one of the top users of the internet in Africa which has tripled that of its rival country, Kenya, with the growth majorly in broadband. It has taken to the use of mobile phones to bridge the digital divide. Fig. 8 below gives the approximate number of subscribers per 100 inhabitants of mobile communication (GSM) from year 2000 to 2012 [19].

Mobile phones are more affordable and have more diffused signals than the personal computers. The use of smart-phones, which have made it possible to connect to the internet, have made it easier to combine the functions of both PCs and Mobile phones.

Presently, Nigeria has embarked on the installation of about five submarine cables (SAT-3, WACS, GLO1, 
MAIN ONE and ACE) and more are being installed with terabytes of data and national fiber backbone networks for the expansion of the use mobile phones in order to ensure the realization of e-governance. With further expansions and improvements in the use of GSM, people will be encouraged to actively participate in e-governance, thereby actualizing the dream to make Nigeria an e-governable nation.

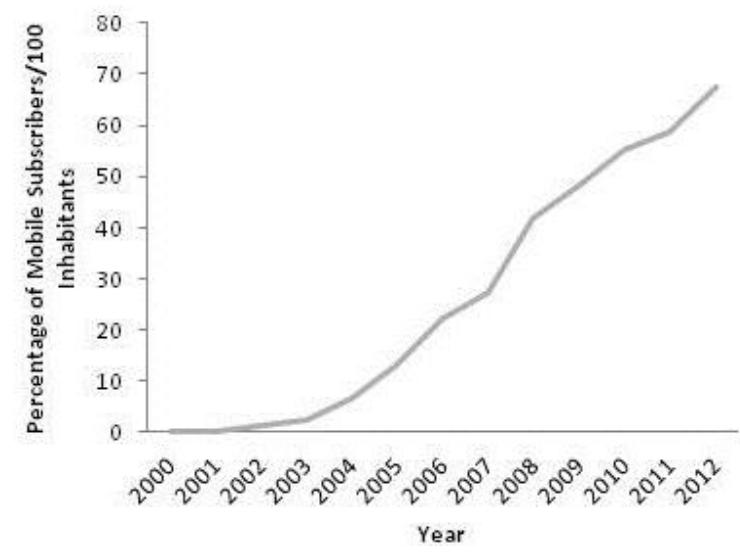

Fig. 8. Line graph indicating number of phone subscribers

\section{Nigeria's e-Readiness and e-Participation}

Nigeria has improved in several dimensions in terms of IT and advancement especially within a government to citizen (G2C) and government to employees (G2E) dimensions.

For instance, in terms of $\mathrm{G} 2 \mathrm{C}$ dimension, one remarkable transformation is in the Joint Admission Matriculation Board (JAMB) which has been revolutionized today. Answer scripts are now computer marked and loaded onto the website so that results can be checked within 7 days after the examination had been written. Therefore, errors can be minimized in the place of marking, release and dispatching of results and everything that has to do with the examinations. Also, with a vehicle population of over 200,000, updating and checking of licenses and particulars have been made easier as drivers and vehicle particulars are currently electronically encoded [15].

In terms of G2E dimensions, e-payments are now used for payments of salaries, procurements and contracts making it easier for employees to receive and withdraw cash. This e-payment has also made it easier to move cash generated from public sector and eliminate the high risks involved. Electronic transactions are gradually gaining grounds thereby causing a shift from the cash transactions that can be very risky, and also helping to curb financial crimes and money laundering. All these have helped to ensure workers get their salaries within few hours of payment, instead of the usual waiting for days before they get their payments effected [15].

Currently, access to the allocations for local and state governments are provided on the website of the Ministry of Finance website. With this transparency, local monitoring of how expenditures are incurred is possible [20].

The United Nations' global survey reports some ICT indicators that point to the measure of how far a nation has gone in the implementation of e-governance such as:

- E-readiness - This indicator is used to assess how prepared a nation or a community is to integrate ICT into every aspect of their economy in terms of what they have and have put in place. It compares the ranking of the countries of the world according to e-government readiness and e-participation.

- Web measure index - this indicator defines the stage of e-readiness based on the presence or absence of some particular available e-facilities and services.

- Telecommunications infrastructure index - this can be measured in five different ways thus; PCs/100 persons; internet users/100 persons; telephone lines/100 persons; broadbanding/100 persons; mobile phones/100 persons. It then assigns each variable a $20 \%$ weight.

- Human capital index - this indicator is composed of a combination of adult literacy rate and primary, secondary and tertiary gross enrollment ratio, giving two third of the weight to adult literacy and one third to the other gross enrolment ratios.

- E-participation index - this indicator measures the usefulness and the frequency of the provided services [8].

Tables 1 and 2 [8] below highlight Nigeria's e-readiness, e-participation and infrastructural indices in the years 2004, 2005 and 2008.

Table 1. Nigeria's e-readiness/e-participation index

\begin{tabular}{|c|c|c|c|c|c|c|c|}
\hline Year & $\begin{array}{l}\text { Web } \\
\text { measu } \\
\text { re } \\
\text { index }\end{array}$ & $\begin{array}{c}\text { Infras } \\
\text { tructu } \\
\text { re } \\
\text { index }\end{array}$ & $\begin{array}{l}\text { Hum } \\
\text { an } \\
\text { capit } \\
\text { al } \\
\text { inde } \\
x\end{array}$ & $\begin{array}{l}\mathrm{e}- \\
\text { readin } \\
\text { ess } \\
\text { index }\end{array}$ & $\begin{array}{c}\mathrm{e}- \\
\text { readi } \\
\text { ness } \\
\text { rank }\end{array}$ & $\begin{array}{c}\text { e-parti } \\
\text { cipatio } \\
n \\
\text { index }\end{array}$ & $\begin{array}{c}\text { e-p } \\
\text { arti } \\
\text { cipa } \\
\text { tion } \\
\text { ran } \\
k\end{array}$ \\
\hline 2008 & .2241 & .0492 & .648 & .3063 & 136 & .0682 & 116 \\
\hline 2005 & .2231 & .0143 & .59 & .2758 & 139 & .0794 & 39 \\
\hline 2004 & .143 & .013 & .59 & .248 & 141 & .0656 & 33 \\
\hline
\end{tabular}

Table 2. Nigeria's Infrastructural Index

\begin{tabular}{|c|c|c|c|c|c|c|}
\hline Year & $\begin{array}{c}\text { Intern } \\
\text { et } \\
\text { users } \\
\text { index }\end{array}$ & $\begin{array}{c}\text { PC } \\
\text { index }\end{array}$ & $\begin{array}{c}\text { Tel } \\
\text { lines } \\
\text { index }\end{array}$ & $\begin{array}{c}\text { Mobil } \\
\text { e } \\
\text { subscr } \\
\text { iption } \\
\text { index }\end{array}$ & $\begin{array}{c}\text { Broad } \\
\text { band } \\
\text { index }\end{array}$ & $\begin{array}{c}\text { Infrastru } \\
\text { cture } \\
\text { index }\end{array}$ \\
\hline 2008 & 0.067 & 0.01 & 0.013 & 0.156 & 0 & 0.0492 \\
\hline 2005 & 0.009 & 0.009 & 0.0066 & .0214 & $\begin{array}{c}\text { Not } \\
\text { used }\end{array}$ & 0.0143 \\
\hline 2004 & 0 & 0 & 0 & 0 & $\begin{array}{c}\text { Not } \\
\text { used }\end{array}$ & 0.013 \\
\hline
\end{tabular}




\section{PROPOSED NETWORKING MODELS}

\section{A. Networking Model for E-Management Implementation}

Towards achieving a more efficient implementation of e-governance in Nigeria, [8] proposed the integration and coherence of all government's websites and e-government policies, under an agency of the government. He suggested a national e-government portal, designed, implemented and maintained by the selected agency. However, considering the successful implementation of e-governance in other developing countries, like China which had as at January 2009 around 45,555 government websites suffixed with 'gov.cn' [9], having just one national portal may not support an efficient implementation. Yet, it may be necessary to have a national portal which will serve to provide information and e-government services to business and citizens, while at the same time coordinating other government websites. The national portal must be designed such that it is synchronized with other government MDAs' portals as to enable e-management of cross flow of data and information among the MDAs.

Fig. 9 below gives the networking model for actualizing efficient e-management of government's e-resources. In other words, this model enables efficient implementation of Government-to-Government dimension of e-governance, and the provision of shared services.

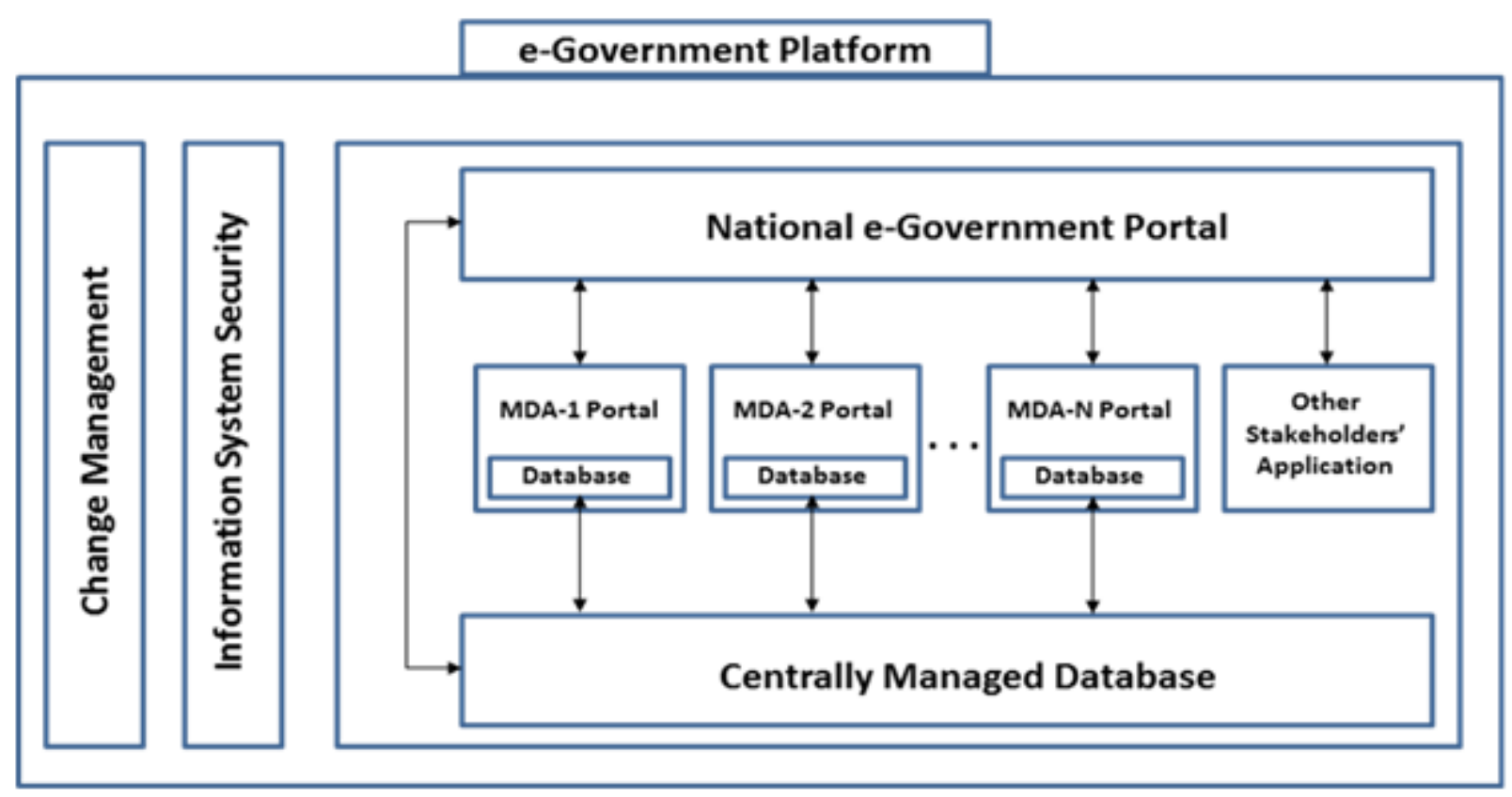

Fig. 9. Networking model for e-management

MDAs in this context include all government ministries, departments, agencies, and other special agencies and arms of government (CBN, EFCC, Police, Military, judiciary, legislative, etc).

The national portal is expected to be managed by a selected government agency. This agency also serves as the change manager. On the other hand, each of the MDAs develops its own website, using a common framework, with each providing specialized services to businesses and citizens. While each uses a dedicated database, a centralized database is also adopted to provide data back-up and restore services to all the databases of the MDAs. This provides a platform for harmonizing all MDAs' data, thereby monitoring their activities, whilst easing e-management. The other stakeholders in this model are private partners in the NeGSt. It must be noted that their applications are only linked to the national portal. These applications, amongst other things, may be solutions embedded on the national portal.

In summary, the model encompasses the following:

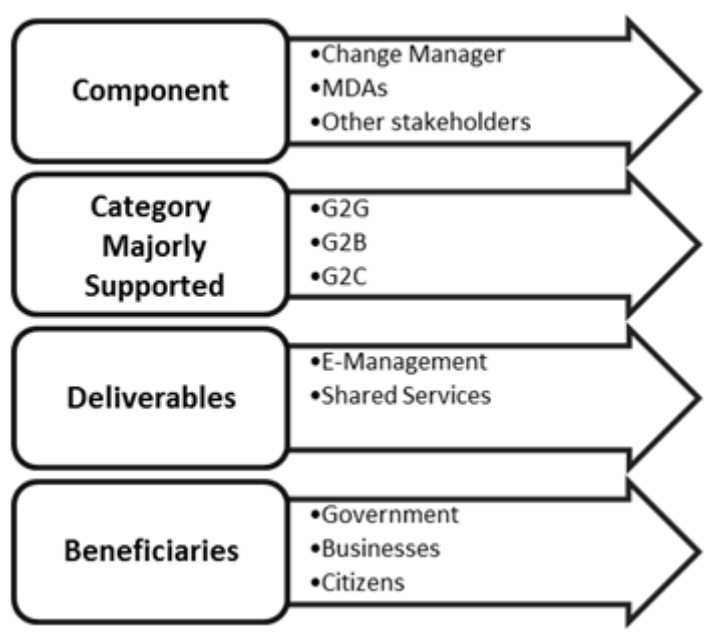

Fig. 10. Summary of networking model for e-management

This model is expected to be implemented at the national and state levels. Efforts must also be made to 
ensure the portals are accessible to all categories of citizens who wish to access them. It has been shown recently that accessibility guidelines, meant to ensure equality of access to both able and disable citizens, are not often taken into considerations by designers of government website [21].

Two other important factors to be considered in the design of websites are ease of use and usefulness. Positive correlation between ease of use and adoption has been established [22]. The central e-government portal would help to achieve perceived usefulness. While the different portals belonging to the different MDAs will provide specific contents, it is expected that most of the general information commonly required by majority of visitors would be available on the central portal.

It is noteworthy that efforts to promote the country's code Top Level Domain (ccTLD), .ng, have been heightened by the Federal Ministry of Communications Technology. Through the 'Switch to gov.ng' initiative, the Ministry aims to foster the adoption and penetration of the unified email platform for the federal public service [23]. This should be made to trickle down to the state and local government levels.

B. Networking Model for Implementing e-Service, e-Democracy, and e-Commerce

On one side are the users who desire to benefit from services provided by their government, participate in governance, and fulfill their obligations as citizens and businesses. On the other side is the government, meant to provide the needed platform to satisfy its populace. This model proposes an interface to connect both parties. This interface comprises of hardware, business entities, and other intermediaries. These include mobile technology, internet, communication service providers (CSP), and common services centers (CSC). This interface acts as a service delivery gateway, a middleware through which services are routed between government and users [24].

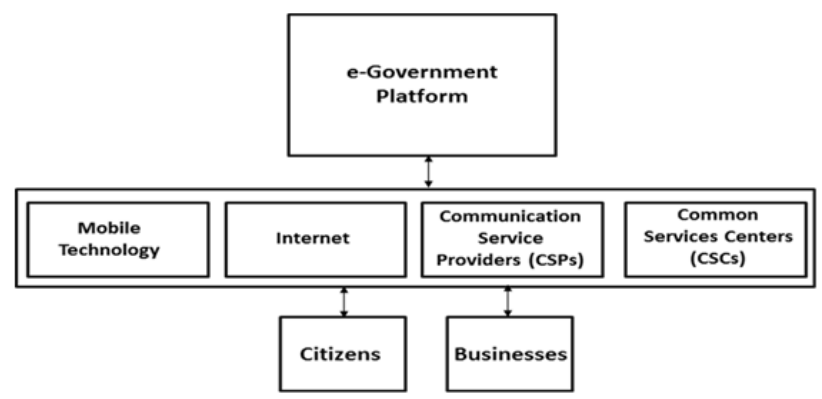

Fig. 11. Networking model for implementing e-Service, e-Democracy, and e-Commerce

Communication Service Providers (CSPs) are expected to be play active roles in the national quest to actualize efficient implementation of e-governance. These are GSM providers, and Internet Service Providers (ISPs). They interact daily, one way or the other, with the users. Government can only leverage on this relationship.

The Common Services Centers (CSCs) are centers located in rural areas, established by government, equipped with broadband internet [24]. These would serve majorly rural dwellers whose knowledge of phone and/or internet usage is limited.

In summary, the model is constituted in the following:

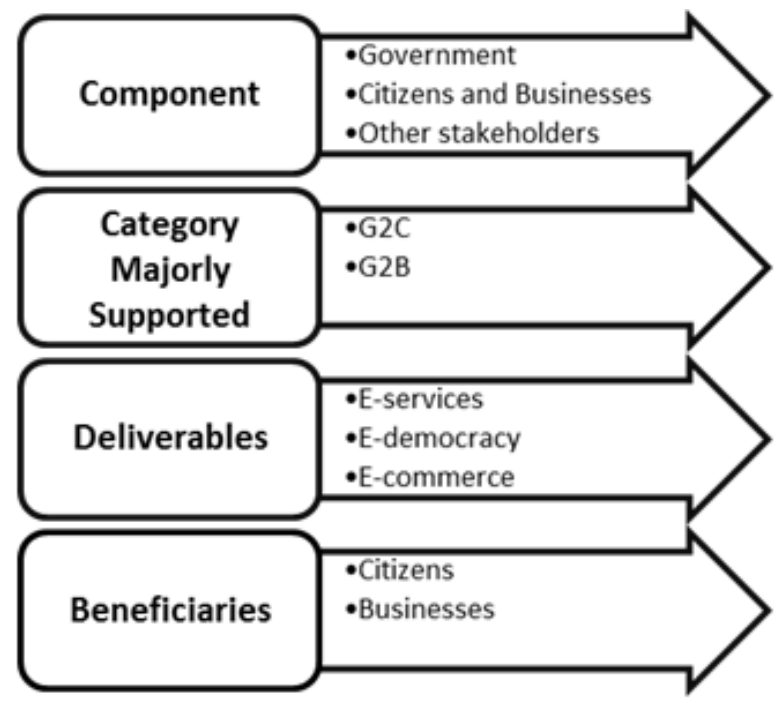

Fig. 12. Summary of networking model for implementing e-Service, e-Democracy, and e-Commerce

For Nigeria, the indispensability of mobile technology and internet in actualizing efficient implementation of e-governance cannot be overemphasized. This is considering the level of utilization of these technologies. Unfortunately, the adoption of mobile technology, by the government, as means of interacting with the citizens, has been relatively poor. Ironically, many private business entities have been leveraging on this platform; though, due to the absence of tight regulations, many have rather been abusing it. Unsolicited SMSes are daily received by mobile users, without the senders providing the means to opt out of the service [25].

Use of mobile technologies for enhancing government's responsibilities to its citizens, known as mobile government (m-government), will significantly improve Nigeria's drive towards increased adoption e-governance. M-government, by way of providing a veritable platform for development and deployment of necessary applications, helps to compliment the efforts of e-government [26].

\section{CONCLUSION}

The main objective of this paper was to propose a networking model that will most effectively support the efficient implementation of e-governance in Nigeria, which is one of the key components of the vision 2020 20 , considering her peculiarities. To actualize this goal of delivering dividends of democracy through the use of ICTs, we proposed a national portal which will serve to provide information and e-government services to businesses and citizens, while at the same time coordinating other government websites. We also recommended the primary use of mobile technology to achieve the delivery of e-Service, e-Democracy, and e-Commerce. This considered the fact that majority of 
Nigerians, both rural and urban dwellers have adopted the use of mobile phones which both educated and illiterates can conveniently use and understand

Nigeria, evidently, would be better for it, with its citizens better satisfied, if e-governance is implemented, as there would be improved general efficiency in public service delivery.

\section{REFERENCES}

[1] Wikipedia, "Government." Retrieved January 5, 2013 from http://en.wikipedia.org/wiki/Government.

[2] K. D. Adejuwon, "From E-government to E-governance: Whither African Public Administration?," Advances in Arts, Social Sciences and Education, Vol. 2 (1), pp. 63 75, 2012.

[3] BSNL Employees Union, "E-governance and Best Practices." Retrieved from http://www.bsnleuap.com/Docs/ annex_6 $6^{\text {th }} \% 20$ CPC.pdf.

[4] D. Zissis, and D. Lekkas, "Securing e-Government and e-Voting with an Open Cloud Computing Architecture," Government Information Quarterly, 28, pp. 239 - 251, 2011, doi:10.1016/j.giq.2010.05.010.

[5] D. B. Dhami, "e-Governance in Nepal: Prospects and Challenges in Implementation," Unpublished.

[6] M. Sakowicz, "How to Evaluate E-Government? Different Methodologies and Methods," in 11th Annual NISPA Conference, Romania, 2003. Retrieved from http://unpan1.un.org/intradoc/groups/public/documents/ni spacee/unpan009486.pdf/.

[7] D. Gichoya, "Factors Affecting the Successful Implementation of ICT Projects in Government," The Electronic Journal of e-Government, Vol. 3(4), pp. 175 184, 2005.

[8] A. B Adeyemo, "E-government Implementation in Nigeria: An Assessment of Nigeria's Global e-Gov Ranking," Journal of Internet and Information System, Vol. 2 (1), pp. 11-19, 2011.

[9] L. Guanghua, "e-Government, People and Social Change: A Case Study in China," The Electronic Journal on Information Systems in Developing Countries, Vol. 38(3), pp. $1-23,2009$.

[10] B. R. Prasannakumar, "E-Governance and Service Delivery-Scope and Implementation Issues." Retrieved $\begin{array}{lll}\text { February 12, } 2013 \quad \text { from } & \text { 12 }\end{array}$ www.kerala.gov.in/publications.htm.

[11] N. Vijakumar, "Role of ICT in e-Governance: Impact of Cloud Computing in Driving New Initiatives," SetLabs Briefings, Vol. 9, No.2, pp. 43 - 52, 2011.

[12] W. Scacchi, "Process Models in Software Engineering," in Encyclopedia of Software Engineering, 2nd. Edition, J. Marciniak, Ed, Wiley, 2002, pp. 993 - 1005.

[13] Wikipedia, "Process Modeling." Retrieved November 25, 2014 from http://en.wikipedia.org/wiki/Process_modeling.

[14] O. Agunloye, "Strategies for Implementing the Nigerian eGovernment and ePayment Initiative," in NITDA eNigeria 2010 International Conference and Exhibition, May, 2010.

[15] D. Akunyili, D, "ICT and e-Government in Nigeria: Opportunities and Challenges," in World Congress on Information Technology, The Netherlands, June, 2010. Retrieved from http://goafrit.wordpress.com/2010/06/12/ ict-and-e-government-in-nigeria-prof-akunyili/.
[16] O. Olowu, "Nigeria to have Direct Internet Access in 2013," Mobile World, June, 2012. Retrieved from http://www.mobileworldmag.com/nigeria-to-have-direct-i nternet-access-in-2013.

[17] P. Obi, "NITDA: Over 44m Internet Users in Nigeria," ThisDay, September, 2012. Retrieved from http://www.thisdaylive.com/articles/nitda-over-44m-intern et-users-in-nigeria/113242/.

[18] Wikipedia, "List of countries by number of internet users." Retrieved January 7, 2013 from http://en.wikipedia.org/wiki/List_of_countries_by_numbe r_of_Internet_users.

[19] O. Osho, F. A. Adesuyi, and S. M. Abdulhamid, "Combating Terrorism with Cybersecurity: The Nigerian Perspective," World Journal of Computer Application and Technology, Vol. 1(4), pp. 103-109, 2013, DOI: 10.13189/wjcat.2013.010401.

[20] S. Mohammed, M. K. Abubakar, and A. Bashir, "eGovernment in Nigeria: A Catalyst for National Development," in $4^{\text {th }}$ International Conference on Development Studies, Nigeria, April, 2010.

[21] S. A. Adepoju, I. S. Shehu, and P. Bake, "Accessibility Evaluation and Performance Analysis of e-Government Services in Nigeria," in $6^{\text {th }}$ International Conference of Information and Media Technology, Dubai, December, 2014 (Accepted).

[22] V. kumar, B. Mukerji, I. Butt, and A. Persuad, "Factors for Successful e-Government Adoption: A Conceptual Framework," The Electronic Journal of e-Government, Vol. 5 (1), pp. 63 - 76, 2007.

[23] E. Okonji, "Minister Unveils 'Switch to .gov.ng' Initiative for Federal Civil Service," ThisDay Newspaper, November 27, 2014, pp. 24.

[24] R. Chauhan, "National E-governance Plan in India (UNU-IIST Report No. 414),” 2009. Retrieved from https://www2.iist.unu.edu/www/docs/techreports/reports/r eport414.pdf

[25] O. Osho, O. Y. Ogunleke, and A. A. Falaye, "Frameworks for Mitigating Identity Theft and Spamming through Bulk Messaging," in IEEE $6^{\text {th }}$ International Conference on Adaptive Science and Technology, Ota, Nigeria, October, 2014.

[26] I. kushchu, and M. H. Kuscu, "From E-government to M-government: Facing the Inevitable," Mobile Government Lab, May, 2014. Retrieved November 24, 2014, from http://unpan1.un.org/intradoc/groups/public/ documents/apcity/unpan045367.pdf.

\section{Authors' Profiles}

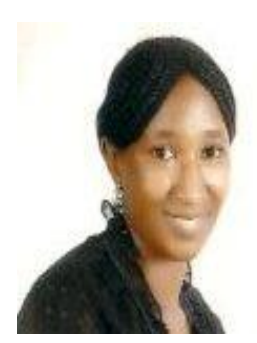

Lauretta Oluwafemi Osho is currently a Master degree student in the Department of Computer Science, Federal University of Technology, Minna. She holds a B.Tech. degree in Mathematics/Computer Science. Her research interests include cloud computing and software development. 


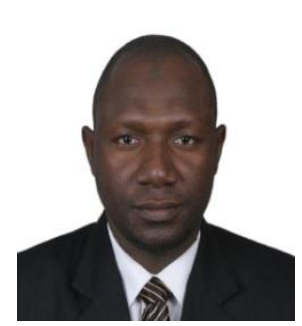

Muhammad Bashir Abdullahi received B.Tech (Honors) in Mathematics/Computer Science from Federal University of Technology, Minna, Nigeria, and Ph.D. in Computer Science and Technology from Central South University, Changsha, Hunan, P. R. China. His current research interests include trust, security and privacy issues in data management for wireless sensor and ad hoc networks, cloud computing, big data technology and information and communication security.

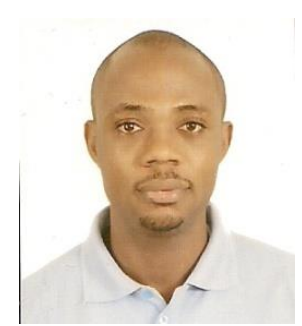

Oluwafemi Osho is currently a lecturer in the Department of Cyber Security Science, Federal University of Technology, Minna, Nigeria. He holds a B.Tech. degree in Mathematics/Computer Science and an M.Tech. degree in Mathematics. Before joining the institution, he served as Head of the IT Department of one of the leading mortgage banks in Nigeria. His current research interests include cybersecurity, mobile security, and security analysis.

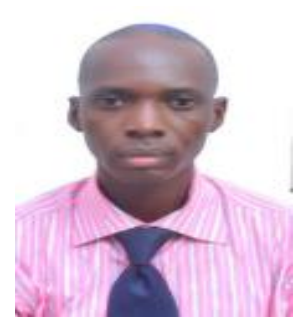

Dr. J. K. Alhassan was born at Ganmu-Alhaeri, in Kwara State, Nigeria on $9^{\text {th }}$ January, 1974 and obtained Bachelor of Technology in Mathematics/Computer Science, at Federal University of Technology, Minna, Niger State, Nigeria in 2000. Then Master of Science in Computer Science, at University of Ibadan, Nigeria in 2006, and Doctor of Philosophy in Computer Science, at Federal University of Technology, Minna, Niger State, Nigeria in 2014. The major field of study is computer science.

He carried out part of his PhD research at United Institute of Informatics Problems, National Academy of Sciences of Belarus (UIIP NASB) Minsk, Republic of Belarus. He is currently a lecturer at the Department of Computer Science, Federal University of Technology, Minna, Niger State, Nigeria. $\mathrm{He}$ has published twelve journal articles and in four conference proceedings. His research interest includes Artificial Intelligence, Data Mining, Internet Technology, Database Management System, Software Architecture, Machine Learning, Human Computer Interaction and Computer Security.

Dr. Alhassan is a member of Computer Professionals Registration Council of Nigeria (CPN).

How to cite this paper: Lauretta O. Osho, Muhammad B. Abdullahi, Oluwafemi Osho, John K. Alhassan,"Effective Networking Model for Efficient Implementation of E-Governance: A Case Study of Nigeria", IJIEEB, vol.7, no.1, pp.18-28, 2015. DOI: 10.5815/ijieeb.2015.01.03 